\title{
PERAN PENGELOLAAN USAHA TOKO ELEKTRONIK DESA TAJUN BAGI MASYARAKAT SEKITAR
}

\author{
Made Difa Artha Saputra, Ni Putu Gina Puspita Dewi, Luh Ayu Rentini, Ni Made \\ Ayu Krismayanti \\ Jurusan Akuntansi, Universitas Pendidikan Ganesha, Singaraja, Buleleng, Bali
}

\begin{abstract}
Abstrak
Penelitian ini bertujuan untuk menginvestigasi adanya potensi penyimpangan pada organisasi pemerintahan. Investigasi dilakukan dengan menggunakan pendekatan Fraud Triangle pada dinasdinas di Kabupaten Buleleng-Bali. Pengumpulan data dilakukan melalui metode wawancara dan dokumentasi. Hasil penelitian menunjukkan bahwa terdapat potensi kecurangan pengelolaan keuangan akibat kurangnya pengawasan yang dilakukan. Dalam kaitannya dengan Fraud Triangle, inin berhubungan dengan aspek opportunity (kesempatan) yang memungkinkan tindakan kecurangan dapat terjadi.
\end{abstract}

Kata kunci: Fraud triangle; organisasi pemerintahan; Buleleng

\section{Abstract}

This study aims to investigate the potential for irregularities in government organizations. Investigations were carried out using the Fraud Triangle approach in agencies in the Regency of Buleleng, Bali. Data collection is done through interviews and documentation. The results showed that there was potential for financial management fraud due to lack of supervision conducted. In connection with the Fraud Triangle, this is related to the opportunity aspect (opportunity) that allows fraud to occur.

Keywords: Fraud triangle; government organization; Buleleng

\section{Pendahuluan}

Negara Indonesia dibagi menjadi 34 provinsi, yang dimana setiap provinsi tersebut terdiri atas Pemerintah Daerah kabupaten/kota. Pemerintah pada hakikatnya memiliki tiga fungsi utama yakni fungsi stabilisasi, fungsi distribusi dan fungsi alokasi. Pemerintah Pusat melaksanakan fungsi distribusi dan fungsi stabilitas, sedangkan Pemerintah Daerah yang melaksanakan fungsi alokasi hal ini dikarenakan Pemerintah Daerah lebih mengetahui kebutuhan, kondisi, dan situasi masyarakat setempat. Dalam rangka penyelenggaraan otonomi daerah inilah, pelimpahan, penyerahan dan penugasan urusan pemerintahan kepada Daerah secara nyata dan bertanggung jawab harus diikuti dengan pengaturan, pembagian, dan pemanfaatan sumber daya nasional secara adil, termasuk pembagian kewenangan dalam pengelolaan keuangan negara dan perimbangan keuangan antara Pemerintah pusat dan Pemerintahan Daerah.

Menurut UU No. 32/2004 tentang pemerintah daerah, Desa merupakan bagian dari pemerintah kabupaten/kota yang diatur dalam pasal 200 ayat (1) yang berbunyi antara lain. " dalam pemerintah daerah kabupaten/kota dapat dibentuk pemerintah desa". Kata "Desa" berasal dari bahasa Sangsekerta yaitu "Dhesi" yang memiliki arti tanah kelahiran. Istilah Dhesi telah di gunakan sejak tahun $1114 \mathrm{M}$ yang ketika itu di Indonesia hanya terdiri dari beberapa kerajaan saja. Desa adalah kesatuan masyarakat hukum yang memilki batas wilayah yang berwenang untuk mengatur dan mengurus urusan pemerintah, kepentingan masyarakat setempat berdasarkan inisiatif masyarakat itu sendiri. Desa merupakan bagian dari sector pemerintahan yang memiliki sistem pemerintahan tersendiri yang terdiri atas kepala desa, perangkat desa, dan badan permusyawaratan desa (BPD). Dilihat dari sisi peran dan fungsinya, desa bisa dikatagorikan kedalam tiga jenis. Pertama, desa adat (Self Governing Community). Kedua, Desa Otonom (Local Self Government). Ketiga, Desa Administratif (The Local State Government). Dalam menjlankan sistem pemerintahannya, 
desa memerlukan aktivitas-aktivitas yang mendukung kegiatan disektor pemerintahan, dimana salah satu kegiatannya menyangkut mengenai pengelolaan keuangan.

Keuangan dapat diartikan sebagai suatu bidang yang mempelajari tentang bagaimana individu, bisnis dan organisasi dalam mengalokasikan, meningkatkan, dan menggunakan sumber daya yang nantinya akan berkaitan erat dengan kegiatan utama dari individu, bisnis maupun organisasi yang bersangkutan. Bidang keuangan terbagi atas beberapa penggolongan yang salah satunya mengenai keuangan daerah. Jenis penggolongan ini didasarkan atas seberapa besar wilayah cakupan yang ditangani oleh badan yang menyelenggarakan ataupun mengelola keuangan tersebut. Disini keuangan daerah merupakan hak dan kewajiban daerah dalam rangka penyelenggaraan pemerintah daerah yang dapat dinilai dengan satuan uang yang termasuk didalamnya segala bentuk kekayaan yang berhubungan dengan hak dan kewajiban daerah tersebut. Ruang lingkup keuangan daerah meliputi hak daerah untuk memungut pajak daerah, penerimaan daerah, pengeluaran daerah, pengelolaan kekayaan daerah dan yang lainnya. Dari keberadaan beberapa ruang lingkup tersebut tentunya akan berpengaruh besar terhadap bagaimana pengelolaan keuangan yang nantinya akan dilakukan.

Dalam pengelolaan keuangan desa biasanya menyangkut mengenai kegiatan-kegiatan yang meliputi perencanaan, pelaksanaan, penatausahaan, pelaporan dan pertanggungjawaban terhadap pengelolaan keuangan yang telah dilakukan. Biasanya pengelolaan keuangan desa memperoleh pendanaan dari APB Desa serta tidak menutup kemungkinan untuk memperoleh pendanaan dari anggaran pendapatan dan belanja negara (APBN) yang nantinya dana yang diberikan akan dialokasikan pada anggaran kementrian yang nantinya disalurkan melalui satuan kerja perangkat daerah kabupaten/kota. Dalam mengemban tanggung jawab terhadap pengelolaan yang dilakukan maka tentunya dalam aktivitas pengelolaan tersebut dibantu oleh lembaga keuangan desa yang pembentukannya didasari atas pengelolaan keuangan yang dilakukan. Lembaga keuangan desa dibentuk dengan tujuan utama untuk mengembangkan perekonomian desa tersebut. Oleh sebab itu, desa yang memiliki lembaga keuangan yang baik maka secara otomatis desa tersebut akan mampu mengelola keuangan desa yang ada untuk di manfaatkan menjadi sebuah usaha desa yang dapat membantu meningkatkan potensi usaha desa yang ada. Secara singkat kegiatan pengelolaan ini sangatlah berdampak positif bagi desa karena dengan adanya kelimpahan wewenang pengelolaan keuangan akan membuat desa terbantu untuk mengembangkan serta memajukan desa tersebut di berbagai bidang terutama pada bidang keuangan. Sudah seharusnya pihak desa melakukan atau melaksanaan pengelolaan tersebut secara maksimal, karena dampak serta manfaat yang timbul akibat dari pemaksimalan pengelolaan tersebut akan berpengaruh besar terutama bagi masyarakat desa bersangkutan. Dalam hal ini kami tertarik untuk melakukan penelitian mengenai pengelolaan keuangan di Desa tajun, kabupaten buleleng. Di desa ini terdapat sebuah inovasi pengelolaan keuangan yang sangat inovatif yang dapat membantu masyarakat dalam memebuhi kebutuhannya.

Berdasarkan latar belakang tersebut, pertanyaan penelitian yang diajukan adalah: 1) Bagaimana dasar pemebentukan toko elektronik yang dimiliki dan dikelola oleh Desa Tajun? 2) Bagaimana pengelolaan toko elektronik yang dimiliki dan dikelola oleh Desa Tajun? 3) Bagaimana cara penetapan harga produk sehingga dapat lebih terjangkau bagi masyarakat? dan 4) Bagaimana peran dari keberadaan toko elektronik yang dimiliki dan dikelola oleh Desa Tajun bagi masyarakat?

\section{Metode}

\subsection{Desain Penelitian}

Penelitian ini dilakukan untuk mengungkapkan bagaimana kegiatan operasi yang dilakukan pada Toko Elektronik Desa Tajun. penelitian ini menggunakan metode kualitatif yang merupakan merupakan penelitian yang bersifat alamiah atau lebih menekankan pada aspek suatu pemahaman secara mendalam terhadap suatu masalah. Alasan menggunakan 
metode kualitatif ini yaitu karena penelitian kualitatif umumnya digunakan apabila peneliti tertarik untuk memahami suatu fenomena ataupun permasalahan yang sedang terjadi.

Sedangkan data yang muncul dalam penelitian ini berbentuk kata - kata dan beberapanya berbentuk angka. Proses yang digunakan dalam memperoleh data - data tersebut yaitu dengan melakukan wawancara, observasi dan pengamatan pada Desa Tajun secara langsung.

\subsection{Subjek Penelitian}

Subjek penelitian pada riset ini yaitu Toko Elektronik yang dimiliki sekaligus dikelola oleh Desa Tajun.

\subsection{Metode Pengumpulan Data}

Dalam proses pemerolehan data dalam penelitian ini menggunakan 3 metode yaitu : (1) Wawancara langsung; (2) Observasi; dan (3) Pengamatan langsung.

\subsection{Metode Analisis Data}

Teknik analisa data kualitatif dilakukan dengan cara sesuai dengan pendekatan studi kasus, sehingga analisis data yang diperoleh digunakan dengan cara mencermati dan menelaah secara seksama jawaban - jawaban yang didapat dari subjek penelitian. Sehingga nantinya dari proses analisis data tersebut akan secara tidak langsung menjawab tujuan - tujuan riset yang sebelumnya telah dibentuk.

\section{Hasil dan Pembahasan}

3.1. Dasar Pembentukan Toko Elektronik yang dimiliki dan dikelola oleh Desa Tajun

Tajun merupakan sebuah desa yang berada cukup terpencil dan jauh dari pusat perkotaan. Hal ini membuat aktivitas masyarakat pada Desa Tajun masih cenderung tradisional atau terlepas dari pengaruh perkotaan. Dari faktor inilah yang membuat masyarakat Desa Tajun merasa lebih diberatkan ataupun sulit dalam melakukan aktivitas yang hanya tersedia hanya ada pada pusat kota. Salah satu penyebab dari hal ini yaitu faktor jarak yang cukup jauh. Aktivitas - aktivitas yang dilakukan biasanya mencakup jual beli barang, mengurus data kependudukan, masalah pendidikan, dan masih banyak lainnya. Dan banyak orang-orang luar yang menggunakan peluang ini untuk menjual barang-barang kepada masyarakat Desa Tajun dengan harga kredit yang cukup tinggi. Sehingga masyarakat Desa Tajun lebih memilih membeli ke rentenir dibandingkan dengan membeli sendiri ke kota. Masalah yang ditimbulkan dari hal tersebut adalah masyarakat Desa Tajun menjadi dapat kebergantungan pada rentenir tersebut. Dari banyaknya kesulitan dan keterbatasan yang dimiliki oleh masyarakat Desa Tajun membuat salah satu orang terpandang di Desa Tajun memikirkan jalan keluar dari permasalahan - permasalahan yang ada karena dengan permasalahan yang tetap dibiarkan cenderung dapat merugikan masyarakat baik itu pada tenaga, waktu, maupun uang. Salah satu permasalahan yang telah mampu dicari jalan keluarnya yaitu mengenai jual beli barang yang harus dilakukan ke pusat kota. Tindakan yang ditempuh yaitu dengan membentuk badan usaha berupa toko yang dimana menjual barang - barang elektronik, atk, pupuk organik maupun anorganik dan segala barang yang sekiranya dibutuhkan oleh masyarakat Desa Tajun. Toko ini dikelola oleh Desa Tajun dimana keuntungan dari hasil penjualan ataupun pembelian yang dilakukan akan kembali lagi ke Desa Tajun sendiri.

Selain itu latar belakang dibentuknya toko ini yaitu untuk meringankan risiko masyarakat Tajun dari penarikan barang yang telah dibeli secara kredit. Barang yang biasanya dilakukan penarikan ini karena masyarakat tidak mampu untuk membayar cicilan yang mungkin disebabkan karena kurangnya penghasilan yang didapatkan pada saat itu. Disinilah peran pembentukan toko ini dapat menghilangkan resiko tersebut dengan cara pihak desa melakukan kerjasama dengan beberapa toko elektronik besar dari pusat kota dan pihak desa member barang yang diperlukan oleh masyarakat secara tunai lalu kemudian menyalurkannya ke masyarakat secara kredit sehingga urusan kredit akan 
menyangkut kepada desa bukan ke toko langsung. Dari hal itulah resiko penarikan barang dapat lebih diminimalisir.

\subsection{Pengelolaan Toko Elektronik yang dimiliki oleh Desa Tajun}

Mengelola sebuah toko mungkin bagi sebagian orang mudah mampu menguasai untuk menjalankan usaha di toko tersebut namun anggapan itu belum sepenuhnya benar karena dalam mengelola toko tidak memiliki perbedaan dengan pengelolaan usaha - usaha lainnya. Dibutuhkannya perencanaan yang matang untuk membangun dan mengembangkan usaha tersebut untuk mendapatkan hasil yang lebih optimal. Dalam menjalankannya juga dibutuhkan konsep dan strategi pemasaran yang professional yaitu tidak lain untuk bisa lebih unggul dari para pesaing yang ada di sekitar.

Dalam mengelola suatu usaha tidaklah memiliki pengaruh oleh besar kecilnya modal atas usaha itu sendiri. Melainkan hal yang menjadi penentu keberhasilan dari operasional semua usaha yaitu dilihat dari bagaimana cara pengelolaan yang dilakukan agar dapat sesuai dengan kebutuhan toko tersebut sehingga menghasilkan keuntungan laba bagi pemiliknya serta modal yang sebelumnya telah disebabkan dapat kembali dan dapat dikembangkan menjadi lebih besar lagi.

Dari segi pengelolaan yang dipercayai untuk mengelola dan melakukan aktivitas operasional pada toko tersebut adalah para pegawai LPD Desa Tajun. Hal ini dilakukan karena aktivitas operasional pada toko tersebut mengarah pada bidang keuangan sehingga membuat pengelolaan dan pertanggungjawaban keuangan yang menyangkut toko elektronik tersebut dipercayai kepada LPD Desa Tajun. Selain itu pemilihan pegawai LPD sebagai pengelola toko didasari atas basic yang dimiliki oleh para pegawai di bidang ekonomi sehingga kegiatan operasional dapat lebih terjamin. Ada beberapa faktor yang perlu difokuskan atau dicermati dalam mengelola sebuah toko. Faktor - faktor tersebut terkait pada sistem manajemen keuangan seperti pencatatan stok, pencatatan pemasukan dan pengeluaran dan pencatatan keuangan lainnya yang mampu memberikan gambaran nyata kondisi keuangan pada toko tersebut. Pencatatan stok barang biasanya dilakukan setiap hari, dilakukan oleh pegawai LPD Desa Tajun yang ditugaskan untuk menjaga toko elektronik tersebut. Hal yang dilakukan yaitu mencatat barang yang masih tersedia dan yang sudah tidak tersedia, sehingga stok barang nantinya akan selalu ada tidak sampai mengalami kekurangan pada situasi toko mengalami ramai pembeli. Selain itu pencatatan stok juga dilakukan untuk menghindari adanya kehilangan stok yang bisa mengakibatkan kerugian serta kebingungan dalam proses transaksi yang terjadi di toko. Sehingga dengan adanya pencatatan stok ini membuat barang yang ada di toko akan terdata dengan rapi. Sedangkan pencatatan pemasukan dan pengeluaran dilakukan oleh pegawai LPD pada bagian kantor kas.pencatatan ini mendapatkan perhatian khusus karena dapat mempengaruhi penghasilan yang nantinya akan didapatkan. Hal yang biasa dilakukan yaitu dengan membuat sebuah pembukuan yang ditujukan untuk mengontrol semua transaksi keuangan baik pemasukan, pengeluaran, piutang dan utang yang dimiliki oleh toko tersebut. Selain itu dengan adanya komitmen juga memudahkan pengelola dalam mengevaluasi usaha toko untuk memperoleh hasil yang lebih akurat.

\subsection{Cara Penetapan Harga Produk yang lebih Terjangkau}

Penetapan harga produk merupakan salah satu elemen yang sangat penting dalam bauran pemasaran yang berkenaan langsung dengan kebijakan toko mengenai tingkat harga, struktur diskon dan syarat pembayaran. Dari pernyataan tersebutlah dapat diketahui bahwa harga merupakan sejumlah uang yang harus dibayarkan oleh konsumen untuk mendapatkan produk yang dibeli. Dengan penentuan harga inilah seorang pembeli akan membuat sebuah keputusan dalam mengorbankan waktu dan uangnya untuk mendapatkan produk yang sesuai dengan manfaat yang ditawarkan.

Dalam menentukan kebijakan harga memanglah sangat penting serta sulit untuk dilakukan karena penentuan harga menyangkut mengenai banyak hal yang tentunya akan berpengaruh pada pendapatan yang diterima oleh toko. Selain akan berpengaruh secara langsung pada pendapatan toko, penentuan harga juga akan berpengaruh terhadap daya 
saing atas kompetitor yang ada di sekitarnya. Pada toko elektronik Desa Tajun ini, harga yang dibebankan pada setiap produk dapat dikatakan lebih terjangkau jika dibandingkan dengan harga yang ditawarkan oleh toko - toko yang ada di pusat kota. Setelah dilakukan observasi yang lebih mendalam maka diketahui harga tersebut diperoleh dari pengurangan biaya promosi pada setiap produk yang dijual. Kita juga mengetahui dimana keberadaan dari tenaga pemasar tentunya akan membuat suatu nilai jual produk menjadi lebih tinggi karena pihak tenaga pemasar tersebut memperoleh penghasilan yang diambil dari beberapa persen nilai penjualan yang ditentukan. Hal inilah yang mampu dikurangi oleh pengelola toko elektronik sehingga membuat harga pada toko elektronik Desa Tajun menjadi lebih terjangkau.

Masyarakat Tajun cenderung memilih toko ini sebagai sarana dalam melakukan pembelian barang karena dinilai lebih menghemat biaya mereka karena dapat diketahui kembali lagi kepada kondisi lokasi Desa Tajun yang terbilang cukup jauh dari pusat kota yang membuat jika masyarakat Tajun membeli barang di pusat kota terutama barang elektronik yang harus menggunakan jasa angkut untuk mengantarkan barang ke lokasi tujuan secara otomatis tentunya akan memunculkan beban angkut pada setiap produk yang dibeli itulah yang membedakan jika masyarakat membeli pada toko elektronik Desa Tajun. Tentunya mereka bisa menghemat biaya angkut tersebut sehingga membuat besaran dana yang mereka keluarkan menjadi lebih kecil. Dari faktor itulah yang membuat harga yang ditawarkan oleh toko elektronik Desa Tajun lebih terjangkau. Harga yang lebih terjangkau ini telah dibandingkan dengan harga beberapa barang yang dijual oleh Toko Elektronik di pusat kota

\subsection{Peran dari keberadaan Toko Elektronik Desa Tajun}

Menurut observasi yang telah dilakukan keberadaan dari toko elektronik ini sangat memiliki peran yang penting seperti yang sudah dijelaskan pada paragraph - paragraf sebelumnya, dimana toko ini sangatlah membantu masyarakat Desa Tajun dalam hal pemerolehan atau pembelian barang elektronik. Selain itu hasil dari kegiatan operasional toko tersebut tentunya akan disalurkan kembali untuk menambah kas Desa dimana kas tersebut nantinya akan digunakan dalam hal kemajuan Desa Tajun.

Salah satu bentuk keberhasilan dari aktivitas ini yaitu telah dibelinya sebidang tanah yang nantinya akan dibangun sebuah gedung serbaguna. Dimana gedung ini akan disewakan pada orang - orang yang sekiranya memiliki acara dengan lokasi yang mampu menampung banyak orang. Dari kegiatan - kegiatan seperti itulah tidak menutup kemungkinan akan membuat Desa Tajun menjadi Desa yang mandiri dan maju karena mampu memanfaatkan permasalahan yang ada pada Desa tersebut menjadi sebuah peluang dalam usaha menambah pendapatan Desa.

\section{Simpulan dan Saran}

Berdasarkan hasil penelitian tersebut, maka dapat ditarik kesimpulan sebagai berikut

1. Dari rumusan masalah yang pertama dapat ditarik kesimpulannya yaitu dasar pembentukan toko elektronik milik Desa tajun ini adalah Desa Tajun merupakan desa yang terletak cukup jauh dari pusat kota. Sehingga Desa Tajun membentuk sebuah toko elektronik yang dikelola oleh Desa Tajun sendiri dengan harga yang relatif lebih murah dibandingkan harga dari para rentenir atau toko-toko lainnya.

2. Dari rumusan masalah yang kedua, didapatkan hasil bahwa pengelolaan toko elektronik milik Desa Tajun ini dikelola oleh Desa Tajun sendiri yang dipercayakan kepada pegawai LPD Tajun yang sudah diseleksi sesuai dengan kempuannya. Dan melakukan pencatatan stok barang setiap hari, agar dapat mengetahui stok yang masih dan yang sudah habis supaya dapat memesan kembali barang ke supliyer. Agar nantinya barang yang akan di minati pembeli selalu tersedia.

3. Dari rumusan masalah yang ketiga, dapat disimpulkan bahwa cara penetapan harga yang dilakukan toko elektronik desa Tajun sehingga lebih terjangkau adalah barangbarang yang dijual hanya sedikit mengambil keuntungan dibandingkan toko lain. 
Selain itu, keuntungan yang dihasilkan tersebut akan kembali ke Desa tajun sendiri yang digunakan untuk kemajuan esa Tajun sendiri.

4. Dari rumusan masalah yang keempat, dapat disimpulkan bahwa peran dari keberadaan dari toko elektronik milik Desa Tajun ini bagi masyarakat adalah dengan adanya toko ini maka masyarakat lebih mudah mendapatkan barang yang diperlukan, tanpa harus ke kota untuk membelinya yang dimana tentu harganya menjadi lebih mahal dengan transportasi yang lumayan jauh. Selain itu, masyarakat yang belum mempunyai cukup uang dapat mencicil atau mengkredit barang yang diinginkan dengan angsuran yang terbilang sangat kecil. Sehingga masyarakat desa Tajun lambat laun akan mengalami kemajuan dan tidak ketinggalan zaman.

Berdasarkan penelitian ini, maka saran yang dapat diberikan adalah sebagai berikut:

1. Bagi penulis diharapkan lebih menggunakan analisis yang lebih ilmiah lagi dengan data yang lebih kompleks sehingga diharapkan hasil dari penelitian ini lebih akurat.

2. Bagi pengelola toko dan elektronik milik Desa Tajun dharapkan lebih mengembangkan produk-produk yang dijual menambah produk yang dijual agar tidak hanya mencakup barang elektronik saja. Tetapi produk-produk yang dibutuhkan oleh masyarakat Tajun. Sehingga masyarakat tidak ketinggalan zaman.

\section{DAFTAR PUSTAKA}

Doli, D. Siregar. 2004. Manajemen Aset. Jakarta. Satya Graha Tara.

Widjaja, HAW. 2003. Pemerintahan Desa/Marga. PT. Raja Grafindo Persada. Jakarta.

Hanif, Nurcholis. 2011. Pertumbuhan dan Penyelenggaraan Pemerintah Desa. Jakarta. Erlangga.

Sadu Wasistiono \& Tahir, M. Irwan. 2006. Prospek Pengembangan Desa. Bandung. Fokus Media.

Malayu, S.P. Hasibuan . 2007. Manajemen Sumber Daya Manusia, (Ed Revisi 9), Jakarta. PT. Bumi Aksara. 